\title{
"Living and writing in an international space": An Interview with Muhammad Haji Salleh
}

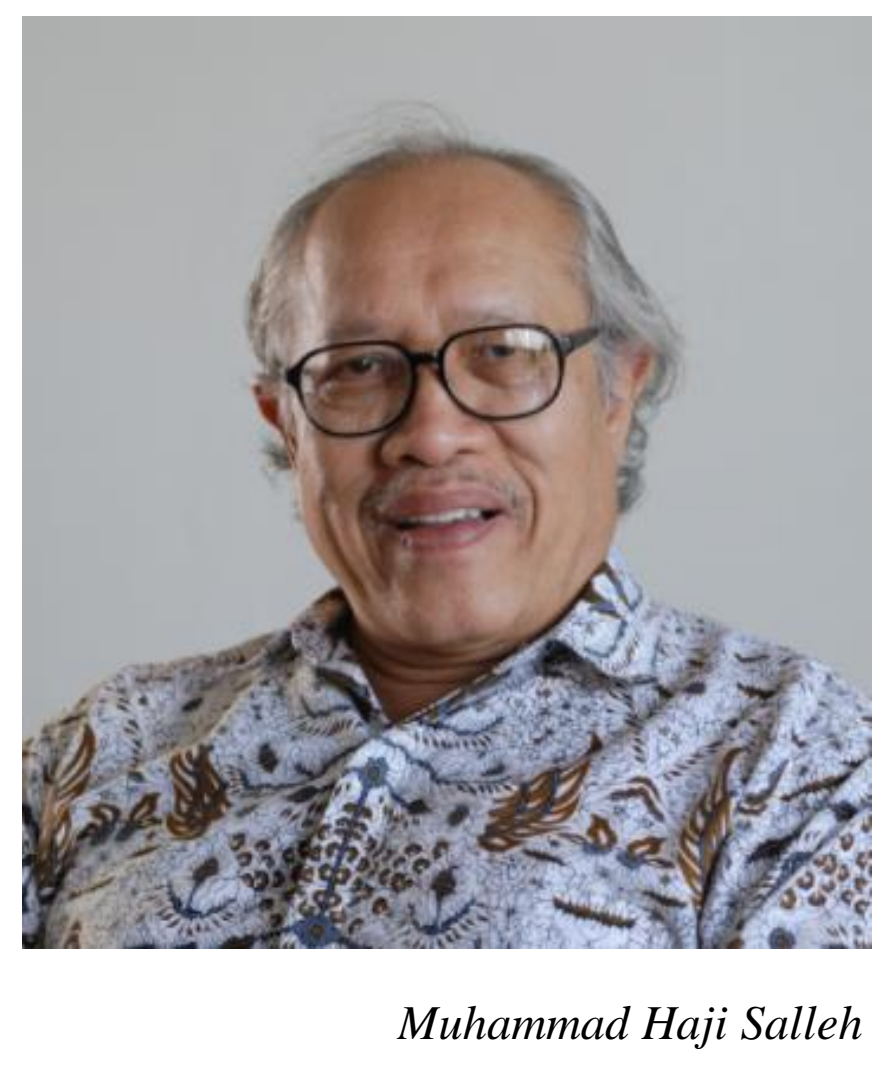

\section{Sharifah Aishah Osman}

Universiti Malaya, Malaysia

Professor Emeritus Muhammad Haji Salleh has had an illustrious career that spans almost 45 years, and he remains actively engaged in creative and scholarly endeavours. As a highly prolific Malaysian poet, literary critic, scholar, and translator of classical and oral texts, his creative works and academic writings have had an immeasurable impact on Malaysian literature and literary studies, both in the Malay and English languages. He has published more than 55 books in both languages, and of his 14 volumes of poetry, several have been translated from Malay into numerous languages, including Mandarin, English, German, Hebrew, Persian, Thai, and Japanese. The many awards and tributes he has received include the ASEAN Literary Award for Poetry (1977), Sasterawan Negara Malaysia, or National Laureate (1991), the SEA Writer Award (1997), National Scholar of Excellence for a Lifetime's Contribution (2008), Tokoh Majlis Sastera 


\section{SARE, Vol. 58, Issue 2 | 2021}

Asia Tenggara, or Southeast Asian Author of Excellence for a Lifetime's Contribution (2015), and the NUMERA International Literary Award (2016). Some of his notable translations of classical Malay literary texts into English include Hikayat Hang Tuah (The Epic of Hang Tuah) (2008) and Sulalat al-Salatin (The Genealogy of Kings) (2020). He has been awarded various academic Fellowships and grants by institutions in the United States, Europe, and Japan, including the Fulbright Fellowship as Asian Scholar-in-Residence, University of Michigan (1981-82), Fulbright Senior Fellow at the University of California, Berkeley (199293), Chair of the Malay Studies Programme at the University of Leiden, the Netherlands (1993-94), Visiting Professor at the University of Hamburg, Germany (1994), Senior Fellow, Center for Southeast Asian Studies, Kyoto University (1999-2000), Writer-in-Residence at the University of Leiden (2005), and a Fellowship at the Harvard-Yenching Institute, Harvard University (2006-7). He is the Founder President of several scholarly associations, namely the Malaysian Folklore Society, the Malaysian Translators Association, the Penang Heritage and History Association, and the Association of Scholars in Malay Studies, all of which demonstrate his continued commitment to the preservation of Malaysian heritage and intellectual traditions. He is currently an Adjunct Professor at International Islamic University Malaysia, Universiti Malaya, Universiti Sains Malaysia, and Universiti Sains Islam Malaysia. This interview was conducted via email in September 2021.

Sharifah Aishah Osman: Thank you so much for agreeing to this interview Professor. Firstly, congratulations on two of your most recent publications, the translated volume of Sulalat al-Salatin (The Genealogy of Kings, or more often translated as Malay Annals) and Seeking Hang Tuah, ${ }^{1}$ your collected essays on the iconic warrior and hero of Malay folklore. Let's begin with your recent edition of the Sulalat al-Salatin. How do you see this volume as a contribution to the field of Malay Studies and Malaysian letters in general, in comparison to previous editions? Were there any issues that you were particularly concerned to improve or revise in this new edition, based on what was already available to scholars and readers in the earlier versions of Sulalat al-Salatin?

Muhammad Haji Salleh: History, as a branch of literature, was written for the benefit of the reader and his community. It is clear that Sulalat al-Salatin came from that concept of literature, where a poem or a story is arranged to bring about some lessons. In this work we are taught by the examples set by the kings, nobles and their ladies. They focus on their magnanimity, courteousness, and generosity. Hang Tuah himself was always kind and a reliable companion, and a leader par excellence.

On a higher moral ground, the characters, including the king, are made to realise that they should be above rumours and calumny. When the sultan did come under its influence, he ordered that the Laksamana be condemned to death, and in turn Melaka was deprived of its greatest warrior and defender. The work 


\section{SARE, Vol. 58, Issue 2 | 2021}

describes the nobility of humility, magnanimity, and courtesy. It also helped to define the arc of authority and responsibility for those in power. More than anything else these moral and the religious spaces were accorded a special place of eminence, for they were seen to be the saviour not only of their own person, but also the villages and the state.

Besides being the productions of the intellectual elite, these works were also seen as the words of the 'sahibul hikayat' (the author of the narrative), 'orang tua-tua' (the older generation), 'orang dahulu kala' (those from the ancient times) who were seen as the wisest in their societies. These composers were also looked upon as being closer to the source of truth and wisdom. Their words were likewise seen as sacred, for they were the teachings of their forefathers, and especially recorded for their descendants. With this preliminary sketch of the didactic nature of Malay literary works vis-à-vis their moral and social functions let us look at one of the most famous of them. The chosen version, as noted earlier, is Raffles MSS 18, the oldest extant manuscript. I have made a new transliteration (1997) of this text and a translation (2020). This manuscript is among the best that is kept in libraries worldwide.

SAO: How can Hang Tuah be made relevant to the younger generation of Malaysians who may not necessarily be very familiar with him and his achievements, given the predominance of Western influence on contemporary popular culture? How do we bring the Sulalat al-Salatin and Hikayat Hang Tuah into the twenty-first century in a practical and accessible way, especially to young audiences?

MHS: These two works are recognized as the greatest of Malay literary works, offering a fine narrative that foregrounds characters that provide numerous episodes that will help us interpret our court culture, the good and just king, the relation of the rakyat and its monarch. In it too we find various other themes that describe the mind of the hero, the nobles, and their rulers. On the other hand, Hikayat Hang Tuah is the only text that gives its pages over to a single human being and traces his achievement, and along with his values and culture, that of the Malays. It still speaks to us, to our present reality, for it describes for the rakyat as Malaysians, Bruneians, Singaporeans, and Indonesians, the very roots of our identity, thoughts, ideals, the philosophy of governance, the responsibility of the ruler and the rights of the rakyat, subjects.

This Hikayat conveys the lessons and wisdom of the past for the generations. These selected lessons and thoughts of the past seem to be as relevant then as they are now, for they consider life and history in the states of the Archipelago, their achievements and failures, the various kings and their successes or otherwise, their personae and impact on the people of the land. Their values and concepts of justice and ethics are described for our consideration and verdict, and so too their ideas of sopan santun and budi bahasa, intricate courtesy and expression of interpersonal relationships. 


\section{SARE, Vol. 58, Issue 2 | 2021}

We are also shown the literary style of the author, and the gems of classical language to tell the truth and define the idea of justice. For those who intend to study the Malays and Malaysia, this work is a valuable introduction to the moral and intellectual life of the times.

I think the work is interesting in itself - it has episodes of bravery, combat, the art of self-defence, intelligence, leadership, magic, and fantasy (which have made a comeback these last few years) - so what is needed is to show it to the young people. We should have more cartoon and anime versions.

SAO: What do you see as some of the cultural baggage associated with the figure of Hang Tuah as an epic hero and icon of Malay nationalism? Is the emphasis on his "Malayness" a unifying or polarizing trait for the development of national identity in multicultural Malaysia?

MHS: The baggage was not Hang Tuah's; it is put there by people who needed to find heroes and idols for their political or social circumstances. I do not think Hang Tuah thinks in their manner. He saw that he needed to complete certain tasks and duties. He had certain skills and he used them to accomplish these tasks. Though there is a location or two where he wanted to show that Melaka too had accomplishments in certain areas, he was not thinking as a Malay, trying to differentiate the different communities in Melaka.

At one point he was sent by the Sultan to buy a specially designed Sri Lankan cloth. However, none of them knew how to sketch the desired design. It fell to Hang Tuah to finish it for the cloth; he was better than those of Sri Lanka. He was not thinking as a Malay, he was thinking as a Melakan. He was a hero of Melaka who happened to be a Malay warrior with great accomplishments.

It is claimed by many "patriots" that Hang Tuah exclaimed, "Takkan Melayu hilang di dunia” ("The Malays shall never disappear from this earth"), which is a very heroic statement and refers to a narrower sense of survival. Hang Tuah worked very hard to defend his king and country. However, if you search through the text of the Hikayat, you will never find such a statement. It is certainly not in the text. Possibly this line came from a play in the 1930s or 1940s (that we are no longer able to identify), but surely not from the Hikayat.

It is well and good to have a role model in Hang Tuah, but it is also good to imitate his achievements. This feeling that the Malays were threatened with the coming of the Chinese and Indians, drove some of the Malays to find heroes who could defend and save them. It was natural for them to choose this supreme Laksamana, but it would be fairer to see him as industrious, brave, courteous, generous, and selfless. These were the exceptional qualities that made Hang Tuah the man.

After the 1950s, it was the new plays, films, and novels which continue to interpret him according to their needs, as the saviour of his people. His identity is what he gave to his people, not what he inherited from them. 


\section{SARE, Vol. 58, Issue 2 | 2021}

YB Steven Sim has lately published a book on him. He seems to have no problems with Hang Tuah, whom he would like to further project as the hero of the Malaysian people.

In Malay literature, many works often promoted religious ideas directly or indirectly. Hikayat Hang Tuah in itself might not be religious, but the idea of a good man, sacrificing for others, being infinitely selfless, for me is to be 'religious'. And the arts have always been used to spread the good values that make us good human beings. As these arts were very popular in the society of that time, they in fact became its medium of thought and values. Their works were used to spread the religion. The wayang kulit, shadow play, in Malaysia especially, was used to spread both Hinduism and Islam. So too among the Javanese; religious stories were enhanced by literary narration.

SAO: What are some of the defining moments of your career, both as a creative writer and an academic? How are they linked to particular issues in Malaysian culture and society that intrigued or inspired you? Has there ever been a time when you favoured one career over the other, and if so, why?

MHS: I initially began to study English Literature, and some Malay Literature too. In the 1960s I began to write in Malay and English. However, in the early 1970s in the USA, I became a student of Comparative Literature, especially Japanese, Chinese, and Latin American. I discovered that the world is bigger than English literature alone, and some other literatures are even more magnificent than English Literature.

In the early 1970s also I rediscovered the Malay Language among the book racks of the Southeast Asian Section in the Library of the University of Michigan. I also realised that I inherited a great and diverse collection of literary texts, which were composed in Kedah, Perak, Pahang, Johor, Kelantan, and Terengganu. But lest we forget they were also composed in Northern, Western, and Southern Sumatera. Many fine pantuns came from Jakarta. In the meantime, hikayats and stories were written in Malay in Acheh, Manado, Ambon, and Ternate. And lately there are many fine poems from the Cocos lslands and Papua. I was awed by these poems and stories, which naturally found their voices in the many local or national dialects.

Later, as I began to research modern Indonesian literature, I entered into a brilliant medium that handled well the contemporary world. It used my language. It dawned upon me that I too should contribute to it by writing more works in it, and experiment with the new elements that I discovered in it, and along the way with my acquaintance with some of the literatures of east and west. And when I lived in Indonesia for a span of time, I noticed that Indonesian writers seemed to have unearthed the numerous gems of the language. The Malay language of the Peninsula and Sumatra has its own special beauty and capabilities, and it has a corpus of more than one thousand titles in classical literature alone, and many of them in their original manuscript forms all over the world. It is indeed a great literature, and I am its heir. 


\section{SARE, Vol. 58, Issue 2 | 2021}

SAO: You once described your ability to write both in Malay and English as being in a state of "linguistic and cultural schizophrenia" ("Decolonization: A Personal Journey" 64). Do you still feel strongly about writing poetry only in Malay, which some critics have described as a deliberate act of decolonization and the expression of linguistic and cultural empowerment ${ }^{2}$ on your part, or have your views changed in recent years?

MHS: That statement was a conclusion to a time when I was struggling to write both in Malay and English. Now I write mostly in Malay and translate Malay works into English and vice versa. I use English to further the case of Malay Literature that has been hidden by colonialism and its followers. The metaphors of Si Tenggang and Hang Jebat naturally found their way into my lines, and it was a process of returning home.

SAO: Which of your works do you consider your most "political", and for what reasons?

MHS: There are a few thousand poets writing in the English Language at the moment, and only a few hundred in Malay and Indonesian. I thought that with my past experience of world literature I might be able to contribute to it more significantly through my mother tongue. And perhaps bring a new perspective and appreciation of the language for the modern period.

In the meantime, these last months, I have also written thirty poems about the stars and the night skies in English, and translated a collection of Malay love pantuns and proverbs into English. Furthermore, I do use a lot of English for my essays, books, and translation work - therefore I use English to give Malaysia a presence in the new century. I am still the incurable linguistic schizophrenic, but not very sick!

I seldom write about politics per se, for in my country politics is incredibly dirty and politicians equally are tainted by dishonesty and corruption. I prefer to write about the general values of justice and fairness, and describe prejudice, the suffering of the helpless villagers here or abroad. They are to be found in several of my books.

However, I consider Sajak-sajak Sejarah Melayu as the most political, i.e. in a broad sense, that is, as it describes and considers the rise and fall of Melaka, its sultans, the chieftains, and the country itself. In them I highlight the generosity and magnanimity of certain sultans and chiefs, and the bias, prejudice, and greed of some others. So, I am more concerned about the country rather than a few corrupt nobles.

SAO: What are some of the significant ways in which your travels and experiences as a global citizen have influenced your identity as a Malaysian author, both earlier in your career, and at present? Do you still view yourself as $\mathrm{Si}$ Tenggang $\mathrm{II}^{3}$, an emblematic figure of your poetic identity that many readers have come to recognize and appreciate? 


\section{SARE, Vol. 58, Issue 2 | 2021}

MHS: If I may say it here, I have been to 70 countries, big and small, old and new, far and near. In my travels I sought out their civilisation, wisdom, their authors, arts and how they care for the people and the environment. I am not afraid of not having an 'identity'. I wish to be known as a Malaysian author who learns from other people and civilisations, which I often describe in their splendour or misery, and I become part of them. I write about the pyramids, Macchu Pichhu, the mosques of Cordoba, the Great Wall of China, but at the same time the wilderness of New York, New Jersey, Kolkata, and Hong Kong. That is my identity, a writer who lives and writes in an international space.

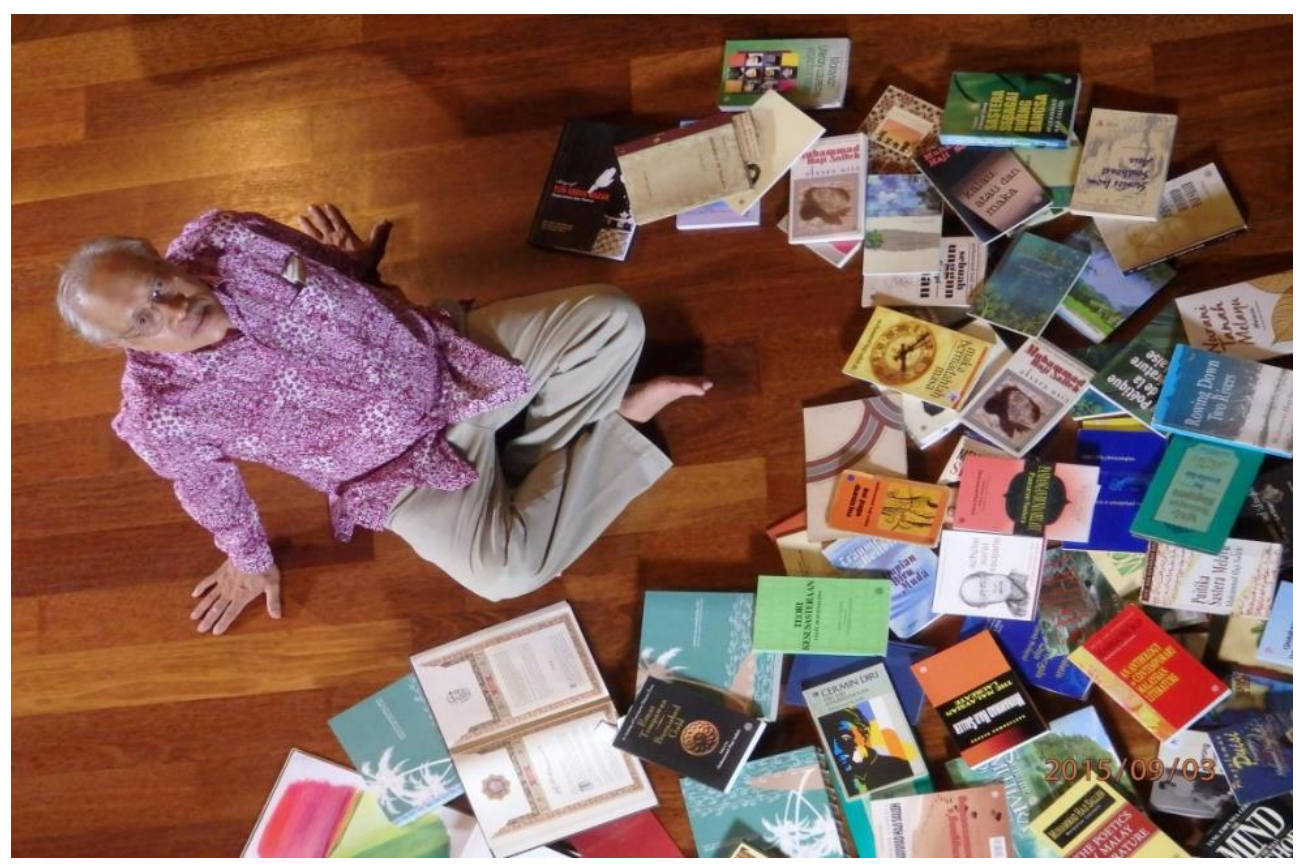

Muhammad with his books (up to 2015)

SAO: What are your thoughts on the state of literary studies in Malaysia, whether at the primary, secondary, and/or tertiary levels? What aspects or policies in our current education system do you think need improvement, or even a total overhaul, in order to facilitate its development or reform?

MHS: There is a concerted and continuous project to dismantle the humanities by politicians who know little about education itself, or the methods of bringing learning and wisdom to our students. The literature class, which is the most effective medium of teaching human values, culture, and identity, is being ripped apart. It is now much smaller, for students are told that they would be unemployed if they insisted on pursuing it. On the other hand, in Europe and in some universities in the USA, literature is open to and enjoyed by all. And in Harvard, I have been told, Shakespeare is the most popular course. 


\section{SARE, Vol. 58, Issue 2 | 2021}

Now with the dismantling of the subject, students don't know who Tun Seri Lanang, or Usman Awang, or Anwar Ridhwan is, and tragically, they don't care. We are also dismantling our culture and civilisation. Can you ever imagine British students not knowing Shakespeare, Lawrence, or Keats?

As they are pulling them apart, literature classes shrink to only a few students, while Malaysians as a people shrink into mere one-dimensional beings. These students too are looked upon as unemployable and therefore have no future. When classes shrink, fewer still will become lecturers. Now there is only one lecturer with a $\mathrm{PhD}$ in folklore, and only three or four in classical literature - where our greatest works are to be found. Education is educating the mind and the heart, the two dominant centres of the human being. Literature helps one experience a wider space of life - in cities and countryside, on the beaches, and among the trees of the forests. You cannot hope to mould a fuller human being by just drilling STEM into him.

Modern literature does find a few more candidates for lecturers. But the Scopus disease that is strangling the university is killing its study of the great and good works. We need in-depth studies of our great poems, hikayats, and novels, and not ten pages of writing to fulfil certain demands for promotion. Shakespeare is great because thousands of books have been written on his plays and poems, and not merely papers written on the way to the associate professorship. If this is the situation, who then is going to write the interpretations of the ideas of our outstanding authors? There is a sense of a slippery hopelessness here. Incidentally there are some good and diligent scholars outside the university who are taking over these difficult tasks. Some of our poets are doctors and engineers, for good (and not for worse) I think.

I think we need to reorganise our classes, from the lowest level to the university. We need to show that while there are lessons to be learnt from literature it can also help give some emotional and intellectual entertainment. Let's not have exams for this subject but make sure that as many as possible participate and enjoy.

SAO: Has the pandemic altered or changed your perspective of life in any profound way? How do you suggest Malaysian authors grapple with some of the unique challenges that have presented themselves in the last year or so?

MHS: I have been retired since 2013, which for us authors, is a kind of lockdown before the pandemic lockdown. I use it as a space to think, work out projects, and perhaps also help younger authors trying to tell their tales. I do more research now than ever before. I read and review works from many lands. And from time to time I translate. No virus is going to stop me from being a writer, translator, and researcher. 


\section{SARE, Vol. 58, Issue 2 | 2021}

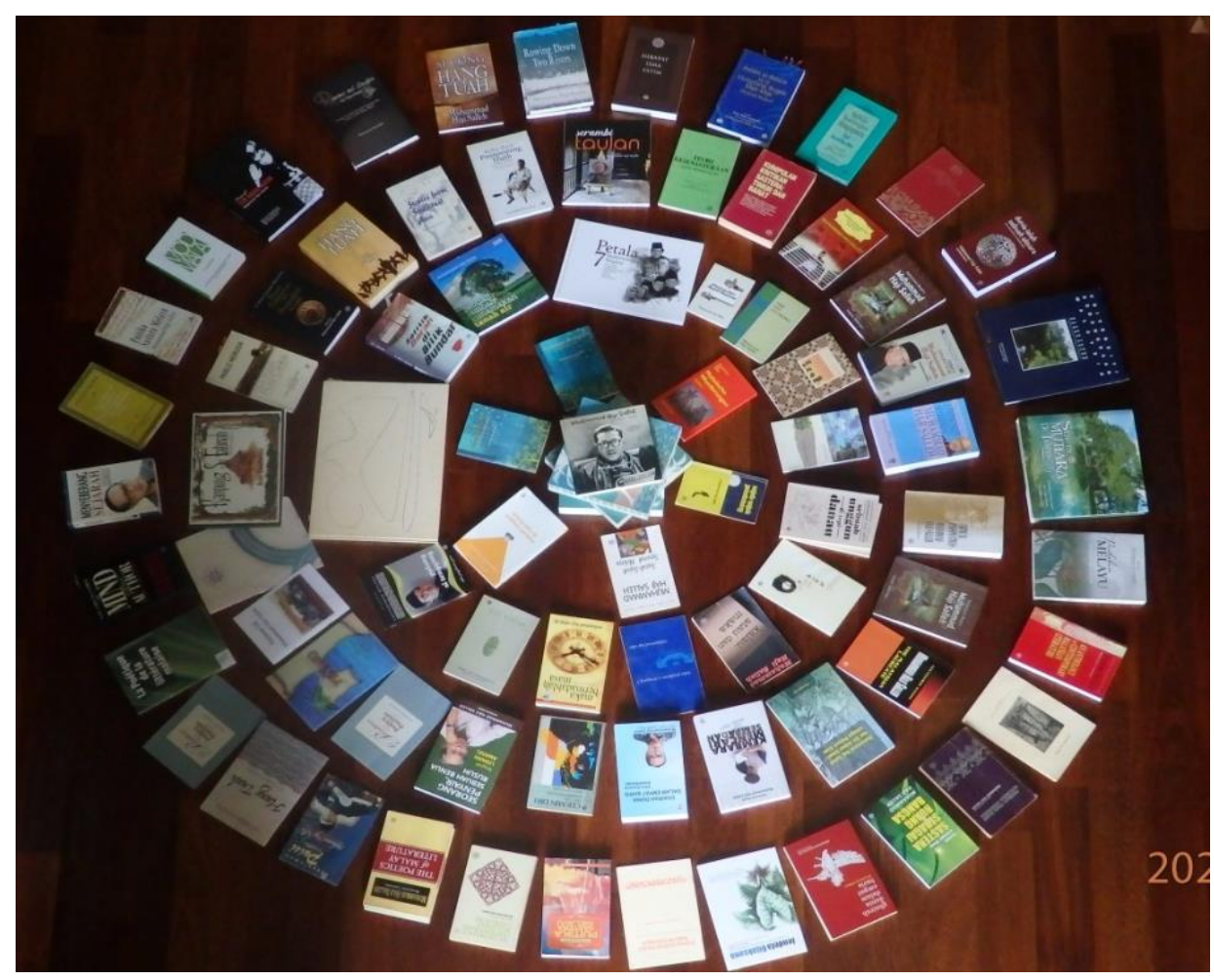

Muhammad's books (up to 2020)

SAO: What projects are you currently working on, and what publications can we expect from you in the near future?

MHS: I am a mad scholar. When I go to the libraries, I notice that there are many things that need to be studied and written about. For example, I have just published two collections of pantuns and proverbs with long introductions. I also noticed that many of them are not translated, so I translated some of them.I also realised that there is no Anthology of Classical Malay Literature to introduce us to the world, so I have put together a big collection (now in the press) of about 500 pages of poems and prose narratives. I also have a book of new poems with the Universiti Sains Malaysia Press, Seratus Pulau di Muara; the second volume of my autobiography, Pulang Si Tenggang; and the second volume of my travelogue, Angin Barat Gelombang Barat, with Dewan Bahasa dan Pustaka. The International Islamic University is publishing Tan Sri Dzulkifli Abdul Razak's biography (which I wrote over these last two years), and my Journey to the Literary Spaces of Malay Literature. So I do still have some tricks up both my sleeves.

SAO: You most certainly do! Thank you again Professor Muhammad, for your generosity and graciousness in agreeing to this interview. 


\section{Notes}

${ }^{1}$ See Tun Seri Lanang, The Genealogy of Kings (Sulalat al-Salatin). Translated by Muhammad Haji Salleh (Singapore: Penguin Books, 2020); Muhammad Haji Salleh, Seeking Hang Tuah (Kuala Lumpur: University of Malaya Press, 2020). Muhammad also published another collection of essays on Hang Tuah in the Malay language recently. See Muhammad Haji Salleh, Hang Tuah di Lautan Ceritera (Pulau Pinang: Penerbit Universiti Sains Malaysia, 2020).

2 Quayum, Mohammad A. "On a Journey Homeward: An Interview with Muhammad Haji Salleh." Postcolonial Text 2.4 (2006): 1-13; Md. Salleh Yaapar. "Si Tenggang in the Postcolonial Arena: A Search for Identity and Sustainability in the Works of Muhammad Haji Salleh." Malay Literature [Online], 26.2 (2013): 154-181. Web. 14 Sep. 2021.

3 In his second volume of poetry, Perjalanan Si Tenggang II (1975), translated into English as The Travel Journals of Si Tenggang II (1979), Muhammad alludes to Si Tenggang, the proverbial figure of the prodigal son from Malay-Indonesian folklore, who is cursed by being turned into stone by his mother for his rejection of his own people and culture. In the poem "Si Tenggang's Homecoming" from the collection, Muhammad revises this narrative to emphasize how his long absence from his homeland, reinforced by the knowledge and wisdom gathered from his travels abroad, has only strengthened his love and loyalty towards his people and his culture.

\section{Works Cited}

Muhammad Haji Salleh. "Decolonization: A Personal Journey." Journal of Commonwealth and Postcolonial Studies 7.2 (2000): 51-67. 